\title{
Enculturation of Ambon's Public Spaces as a Tool of Building Inclusivity of Segregated Communities
}

\author{
Yulita Titik Sunarimahingsih \\ Senior Lecturer of Architecture and Design of Soegijapranata Catholic University, Semarang Indonesia \\ Yustina Trihoni Nalesti Dewi \\ Senior Lecturer of Faculty of Law and Communication of Soegijapranata Catholic University, Semarang Indonesia \\ Heribertus Hermawan Pancasiwi \\ Senior Lecturer of Economics Faculty of Soegijapranata Catholic University, Semarang Indonesia \\ Octavianus Digdo Hartomo
}

Senior Lecturer of Faculty of Law and Communication of Soegijapranata Catholic University, Semarang Indonesia

\begin{abstract}
Beside having significant values that would enrich the Indonesian nation, tribal, cultural, and religious diversity brought seeds of conflicts that could potentially disrupt social order and threaten national unity. The conflicts that occurred in Ambon from 1999 to 2004 were conflict examples that were caused by religious plurality that had appeared many societal problems that could not be fully resolved until today. The trust among Ambon's plural communities had not returned well and it was even worsened by settlement segregation separating Muslim and Christian communities that factually brought potential for further conflicts. In the present life of Ambon's segregated societ today public spaces inspired by brotherhood and "unity in diversity" spirits thatt could be meeting and socializing means of the communities and to reduce the social polarization were to be absolutely necessary. Unfortunately, the existing public spaces in Ambon for the time being served only as stages of activities and they did not connect with the communities' social spectrums so that the public spaces remained meaningless. A public space here served just as a witness, not as a means of socializing in accordance with the communities' cultures and characters. This paper would discuss how to integrate the communities' cultures and characters into a public space design that had significant meaning in overcoming the polarization of Ambon's segregated communities. The public space would be designed by taking into account a location choice where two segregated communities could easily meet. In the public space a macro space concept where the sea as the front page of Ambon communities should be applied and even forwarded since such a concept tended to be forgotten. Beside the spatial format, the public space should also be designed by facilitating various culturalbased activities so that the communities' characteristics that were integrated in the urban culture and daily activities would appear in the public spaces.
\end{abstract}

Keywords: Enculturation, Ambon, Public Spaces, Inclusivity Building

\section{Introduction}

Indonesia's Moluccas islands were historically islands of peace having abundance of local wisdom that nourishes their people. 'Hidop Orang Basudara' was a noble civilization strategy to prevent and resolve conflicts and to build true peace among indigenous Moluccas people. 'Hidop Baku Bae' (peace) was a key word in Moluccas customary values refering to a sacred, dynamic and sustainable process to reconcile and reunite the conflicting parties. 'Hidop Baku Bae' was a customary life achievement that was not just found but it should be consistently and continuously created and built.'Hidop Orang Basudara' and 'Hidop Baku Bae' local wisdoms had become a harmony binding among the Moluccas people for centuries and strengthened solidarity and order in the countries of Moluccas and elsewhere so that they were driven to be agents and pioneers of peace in their own countries and outside the region as well. 
Ambon as the capital of Moluccas that inherites the characteristics of Moluccas' culture ${ }^{1}$ appears as a dense, pluralistic, and segregative city. Since long time, Ambon has a long history as the center of economic interaction, governmental politics, and culture. It is different from most other cities Ambon people were not only inherited by pluralism but they were also characterized by a strict segregation based on religious matters and strict segregation of settlement clusters according to the line of religion that had been established since the time of Dutch colonialism². For the sake of surveillance of the people, the Dutch colonial government reorganized the settlement system that was called Hena or Aman into Negeri (Country) ${ }^{3}$. Therefore any community that used to be called Hena or Aman would change into Negeri. In the socio-historical process, these negeris clustered in certain religion so that there were two religious-based community groups that were later known as Ambon Sarani (Christian) and Ambon Salam (Muslim) ${ }^{4}$

Such segregative dwellings appeared to be one of the triggers of Ambon's long conflict that began in January 1999 which was initiated by dramatically decresing social interaction among Ambonese people. They lived in groups based on religious similarities to form a deeper segregating partition. The social interaction patterns experienced a shift that were marked by the increasingly widespreading interaction pattern having conflictual characteristics. The basic building of a pluralsegregative society seemed to find a consolidation momentum so that it reached a total elimination phase. Public facilities such as markets, schools, hospitals, and others were segregated, such as muslim markets, namely Batumerah and Old markets, and christian markets namely Passo, Tagalaya, and Batumeja markets. This dwelling and other facilities segregation had made Ambon experience social segregation. This condition caused mutual distrust among the people.

The present Ambon communities' socio-cultural condition is in post-conflict reconciliation (of Muslims and Christians) phase after the 1999 conflict. The destruction of public facilities such as education and health facilities have been temporarily fixed and this fact appears to show significant progress. Similarly, the distorting social-cultural relations that affects the social cohesion degree and creates social distance and community segregation have been gradually fixed.

Despite experiencing such distortion that caused disputes or conflicts among communities and created social distance and stretched the social cohesion degree the Ambon communities basically had open, tolerant and appreciative characteristics to cultural diversity, respecting collective life in the spirit of "orang basodara" (brotherhood). These characteristics manifest in their territorial-geneologcal social relationship such as "pela" and "gandong" fraternal cultures or other cultural activities. Ambon communities'cultural characteristics remain having a very strategic potential to be utilized as a safety valve, especially for social stability and security.

The phrase of "Ambon Manise" reflects the totality of the life aspects of Ambon communities, both physically and socially. Physically, "Ambon Manise" means the natural beauty of Ambon City and its environment that is clean, orderly, safe and comfortable; and socio-culturally it reflects to harmonious interaction among the groups and the groups members within the society as it commonly reflects in the cultural fraternity relationship patterns of "pela" and "gandong". The Ambon communities have a philosophy of "Bersatu Manggurebe Maju" which democratically puts forward collective values in order to reach consensus, a teamwork to have a honest, transparent, and democratic competitiond in order to reach safe, harmonious and prosperous Ambon city in the future.

In such a situation the role of public space is significant enough to further strengthen the brotherhood among those who recently had social conflict experiences. This public space is not only understood as physically geographic where the communities gather but it is more as a sphere or environment where the communities will probably interact not only face to face but also to make verbal and inner dialogue. The public space becomes a medium of communication of the Ambon people having kewil habit (to discuss mutual interests) so as to be a mediator of the people's paparipi nature (hurry and rapidly heating up) that usually emerges from private spaces spreading over the city area. Such a space is expected to dilute the differences and to be an arena of amalgamation occurrence (melting pot) meaning the groups and /or individuals

\footnotetext{
${ }_{1}^{1}$ Aholiab Watloly, 2016, "Gambaran Umum Kota Ambon" presented at Focus Group Discussion on Design of Public Space Based on Ambon's Local Wisdoms", Ambon pp. 2-4

2 Tamrin Amal Tomagola, et al, 2007, Format Ulang Birokarasi Kota Ambon, Ininnawa, Makassar.

${ }^{3}$ Abdullah, Subair. 2014, Merayakan Satu Dekade Pasca Konflik: Hidup Harmonis dalam Bingkai Segregasi, Jurnal Studi Islam Volume

3 Nr. 1, 2014

4 Tamrin Amal Tomagola, et al, op.cit.
} 
will voluntarily merge their respective identity so as to facilitate the occurrence of assimilation and cooperation, or at least to build tolerant attitude and behavior among the members of diffrent communities

\section{B. the Characteristics of Ambon's Communities and Ambon City as that is Based on "Orang Basudara" Culture}

The characteristics of Ambon's communities can be read and understood from their various traditions and daily life habits. They, since the beginning of the city construction until today, were made of multi-identity migrant communities, multicultural communities, harbor communities adorned with beach and beautiful sea (water front city). As a hallmark of the urban migrants, the Ambon's communities are embedded in the diversity of ethnic and traditional identities. There are Ambonese, Dutch, Portuguese, Chinese, Arabic, Javanese, Timorese, Kisar, Minang, Tepa, Banda, Tanembar, Babar, Letti and so on which continue to color the Ambon social configuration until now.

Of the Ambon's citizens there are some having ethnic-identity backgrounds of the Netherlands, Portuguese, Arabic, Chinese, and Spanish. There are also citizens coming from ethnic- identity backgrounds of Ambon, Java, Timor, Sulawesi, Toraja, Madura, and so forth. The coming of the migrants did not only happen in the past but it happens until now (post conflict), the Ambon demography continues to grow due to the never stopped migrant influx and they who are interested in the beauty and hospitality of Ambon. Having such a multi-ethnic diversity the Ambon's communities are expected to embrace each other in establishing the identity and togetherness concept as Ambon's citizens in a cross-cutting affiliated identity that are supporting each other. As a result, Ambon's communities having a mixed identity will emerge.

The genuine characteristic of Ambon's citizens from the beginning was open to differences, meaning they were accustomed with mutual attitudes to accept and recognize differences and to build cooperation across differences for the common good. The other characteristics were expressed in inter-racial and inter-ethnic relations in Ambon City where they would always be open to ethnic or racial differences in a cultural identity so the term "Katong Samua Orang Basudara" had become a strong social capital perform the national principle of Bhinneka Tunggal lka (Unity in Diversity) in city called Ambon Manise. The openness and plurality natures makes the Ambon's citizens very sensitive to conflicts eventhough they are factually true peace-lovers (hidop bae-bae). Under these circumstances the existing local wisdom modes in preventing conflict, resolving conflict and building sustainable peace should be the main capital of the Ambon's communities. As a plural society they often experience conflicts but thereis always local wisdom capital that keeps them open for mutual admonition, counseling, and forgiving each other. Katong Samua Orang Basudara is guided by a social ratio that becomes thecustomary ratio of Moluccas or Ambon communities and it becomes a collective mind of civilized Moluccas communities. The Ambon people have always been the reality portrait of Hidup Orang Basudara ${ }^{1}$. The description above shows that the plurality of the Ambon's community must not be used as a means of triggering social conflicts as it is opposed to the authenticity of hearts, characteristics and traditions of the Ambon's communities themselves. The plurality of Ambon's communities could be a social and development capitals to achieve a sustainable development of Ambon City.

\section{Public Space Concept as a Facility for the Segregated Communities Encounters}

A public space as a means of inculturation can be understood as two things, namely public space and public sphere. Public space here means a physical space or place of communities in conducting social activities and a place of social interaction. Such a public space will be a node and landmark of the city navigation tool that could perform as pedestrian, pavement / plaza, public square, and park². A public space as a public sphere was an idea of a Germany philosopher, Jurgen Habermas, who defines public space as a space for critical discussion that is open to all. In this public space, private citizens gather to form a public in which the public reason will be directed to oversee the government's and state's power. The public space here assumes freedom of speech and assembly, free press, and the rights of free participation in political debates and decision-making ${ }^{3}$. Habermas further states that public space is a democratic space that can be used as a vehicle for community discourse, meaning that citizens can express their opinions, interests and needs discursively. A

\footnotetext{
1 Watloly dalam Ralahalu (2012) dan Watloly dkk. (2016)

2 Lynch, K. 1960.The Image of City, MIT Press. Cambridge, MA.

3 Siahaan, James, 2014, Ruang Publik: Antara Harapan dan Kenyataan, www tataruang.atrbpn.go.id/Bulletin/upload/data_artikel/edisi4c.pdf
} 
public space has an important role in the democratic process because it can bethe citizens'arena to communicate with each other regarding their political anxieties ${ }^{1}$.

From the definition, a public space as a plural space is considered as a place of social life of citizens to interact with each other through the democratic principles for the common good ${ }^{2}$ and the arena for the communities to participate in deliberation (on issues of political/policy legitimacy) which is an ideal picture of democracy in which there are justice, diversity, freedom and solidarity values ${ }^{3}$. A public space is not only physical in nature such as a park, a field, a legal institution or organization but the citizens' communiation itself is actually a public space. Therefore, public space should be free, open, transparent and no government intervention as it is autonomous. In other words, a public space should be easily accessible to everyone. From this public space the power of society's or citizen's solidarity can be directed to positive goals and vice versa ${ }^{4}$.

The emergence of social media often called "virtual world" as a new medium provides a wider transformation, both theoretical and practical, on how a public space takes place in a virtual space. The internet's characteristics as a medium, the users accessing, to the information distributed in the virtual (public) space should be of concern how to see the real characteristics of the public space of the virtual world, taking into account the positive and negative aspects 5 . A virtual public space is like a double-edged blade meaning it can quickly change from an assisting tool to a "killer" and vice versa because of its virtual nature, there is no physical presence. Thus, to build harmony in society, we can not rely solely on the development of information technology ${ }^{6}$. No matter how sophisticated the virtual world, it is a world that has no touch of riel sympathy and empathy to be used as a modality of building brotherhood in the real world. Therefore, an encounter place which is the a physical public space to build harmony of the citizens is a necessity that can not be negotiable (conditio sine quanon $\left.{ }^{7}\right)$.

A public space is significant for urban areas and urban life because it is a social construction of a space of spatial behavioral that is defined and to determine the space around us as an integral part of our social existence. Besides, a public space is able to build inclusivity where every community group always has its own belief, character and problem. When it is only self-kept, not communicated with other groups, what will happen is then exclusivity that has the potential to become prejudice seeds, social jealousy, social segregation, etc. What comes later is the feeling of "in group" and "out group" that are easily provoked by irresponsible parties having certain interests ${ }^{8}$. Thepublic space here will be able to play a positive role that can be a space of encounter among communities having different backgrounds and they can interact with each other so that one is to know the others, and vice versa. A public space will not and should not eliminate differences but it can find "links" between different groups of the communities in the form of shared concerns perceived as members of the community, such as education, the environment, economic difficulties, etc. Face-to-face and eye encounters will create a natural, not artificial, sense of sympathy and empathy as it is possible in the virtual world. On the other hand, such a physical public space could be a "cross-cutting affiliation" for all citizens involved although they are different but have shared concerns that must be fought, including the longingness of safe, comfortable, and not bothered by fear and worry life . A public space could also becomes the reintegration of the socio-spatial division so as a mediator between private spaces dominatin the city and it plays an important role in socio-spatial division. Without the mediation process the spatial movement within the city becomes very limited. In relation to this matter, a public space is also considered capable to be a forum for communication and coordination.

\section{Public Space Concept as a Facilities of Ambon Communities Inculturation}

\footnotetext{
1 Noor, Irfan, 2016, Identitas, Agama,Ruang Publik dan Post Sekularisme; Perspektif Diskursus Jurgen Habermas, Jurnal IImiah IImu Ushuludin, (p-ISSN: 1412-5188/e-ISSN: 2549-3752)

2 Kurniawan, Robby.C, 2011, Ruang Publik Pasca Era Reformasi, Jurnal IImiah Administrasi Publik dan Pembangunan, Vol. 2, No. 2, Juli - Desember 2011, hal. 368.

${ }^{3}$ Wicandra OB, 2013, Merebut Kuasa atas Ruang Publik: Pertarungan Ruang Komunitas Mural di Surabaya, Disertasi, Petra Christian University

${ }^{4}$ Pancasiwi, Hermawan, 2016, Budaya Berbasis Kearifan Lokal sebagai Modalitas untuk Perjumpaan dan Interaksi, paper yang tidak dipublikasikan.

5 Ibid

6 lbid

7 lbid

$8 \mathrm{lbid}$
} 
The early building of Ambon's community was based on a hallmark of a harbor-town community, built by the Portuguese and the VOC in the 16th to the 18th century. The social life of the community was systematically designated as a distinctive residential system equipped with beaches, seas, ports and fortified buildings that characterized the "port of town" and merchant community as well as sailors. As a port town community the anthropological characteristics of Ambon's people was always close to the beach and the sea. The characters were also influenced by the local viewpoints of the indigeneousl Ambon's people as other Moluccas' communities living in mountainous areas but they always had a bay or an harbor as an entrance and exit of their respective negeri. They had an intact marine and land zonation system without separating the sea from the land.

Sea water was always to be a social event of together afternoon bathing and swimming after doing activities in the forest or garden. Afer that they then looked for a river to cleanse their body of salty water and the habit was called "spul badan". The romanticism of the beautiful beach and marine having sand and headland had always been a reference to the cosmological identity of Ambon's citizens. Their relationship with the sea and the coast became an inseparable unity. Various songs were created and inherited to remember and restore the freshness of their lives. The songs always told the charm of Ambon city life with its beautiful beach and sea.

The wrting above explains that a public space, in the context of post-conflict Ambon, a public space can play an important role in the socio-spatial division of the Ambon's communities having the anthropological characteristic space concept that is always close to the beach and sea. Sociologically, the Ambon's communities need public spaces arranged with the charm of the sea, beach and headland that will provide a powerful psychological effects to restore the freshness of the existence of "Orang Basudara" culture in a cosmological space and their original nature as a marine love communities having beautiful beaches to build encounter processes and to do consolidation of "Hidup Orang Basudara". The public space management implementing the philosophy of Tempat (tampa) Bakumpul Orang Basudara will make the existing social institutions such as governmental institutions, customary institutions, educational institutions, and communities involve in the management and utilization of the public spaces effectively and efficiently. Thus, the presence of public spaces in Ambon city becomes relevant as a primary need to motivate the lives of Orang Basudara to be more constructive so that the density, narrowness, and social sloth that tend to be social problems in Ambon city will be easily handled. The concept of the macro space of Ambon's communities which is inseparably related to the sea makes the beach a "yard" so that the public space as an encounter space is more precisely placed by the beach. The phenomenon of new development that tends to close the shore makes it necessary to review the policy on the development and urban planning of Ambon city.

The open spaces of Ambon city are designed to support the ecological and socio-cultural benefits that promote people's welfare ${ }^{1}$. Currently the concept of an open space is still directed to a green open space and it is understood as a green park. Seeing the situation of the Ambon city it is necessary to think about open spaces that are not considered only as green parks but they should be more interpreted as spaces that can be utilized as a public spaces where people can interact in them, meet each other and greet without any divider.

A public space in the context of physical public spaces here is a place for community interaction having a social role. In socially critical situation the local wisdom values could be musically elaborated and packaged into messages that must be more "touching" than the speeches or appeals of formal leaders that are often verily normative. Moreover, if such activities in the public spaces are able to invite all parties, particularly the conflicting ones, the social conditions will soon recover and be much more lasting than if they were carried out under pressure or coercion conducted by the authorities. All these can only happen in public spaces that are physically open.

A public space viewed from local wisdom and people's daily life is very close to the original characteristics of Ambon's communities themselves, particularly in building Tempat (tampa) Bakumpul Orang Basudara. The space of Bakumpul Orang Basudara gives a strong cosmological inspiration so that they will understand and accept a public space as a cosmological house of Orang Basudara viewing the object of public space as a house and a yard of Katong Orang Basudara, thus it will awaken a consolidation room of Orang Basudara strongly and firmly inside every public space.

The Ambon' communities, especially the post-conflict Ambon's youths, need public spaces to build encounter processes and to make a consolidation of Hidup Orang Basudara. Public spaces arranged with the charm of the sea, beaches and

\footnotetext{
${ }^{1}$ Rencana Pembangunan Jangka Panjang (RPJP) Kota Ambon, Perda Kota Ambon no. 4 Tahun 2006.
} 
promontory will provide powerful psychological effects to restore the freshness of the existence of Orang Basudara in their a cosmological space and their original characteristics as a sea-love communities having beautiful beaches.

The conflict phenomenon of Ambon's communities is not static but it tends to be dynamic. Conflicting trend that easily changes has a close relationship with 3 dimensions, namely: time, resources and infrastructure ${ }^{1}$. The behavior or Ambon's people that are easy to fight but also easy to reconcile is caused by the behavior that tend to be the fundamental weaknesses of the people, such as kalakuang jumawa that is temparemental and emotional characters. These characteristics make Ambon's people less able to control themselves, easily provocated, doubled with kalakuang paparipi, that is the characteristics of rush and quickly respond. A sense of solidarity that is embroiled in emotion that has been a specific characteristic of Ambon's communities which is a reflection of the sense of brotherhood (Orang Basudara) wrapped with emotional fanaticism tends to harm. On the other hand, the essence of peace and peace modus in indigenous people of Orang Basudara ${ }^{2}$ have three meanings that are free of war, free of civic irregularity, and calmness that balance the three meanings, namely social meaning which creates harmony, tolerance and harmony that are called bakudame deng basudara, the meaning of the nature creating harmony with nature (bakudame deng gunung tanah) and inner meaning creating peace and inner welfare (bakudame deng sanang heart dame deng sanang hati).

Therefore, peace as a process must be planned and executed, not given, it must be built and pursued in Ambon's communities and must be a serious effort. To achieve the peace process, two concepts of reconciliation are made in stages $^{3}$, namely first to build a continuous dialogical relationship, and second to bring and to engage the reconciled parties in an activity which can create dependence on each other. The efforts will be very effective if they are run in a public space conept that became a means of encounter that is based on Ambon's own culture. The public space should be a living rule which in the community of Orang Basudara is called "Atoran" which means that traditional values are used as a sacred norm which serves to direct, control, and reward or sanction ${ }^{4}$. Cultural traditions that must be developed through the public spaces are, among others 5 :

a. the tradition of kumpul basudara (gathering relatives)

b. panas pela (to strengthen kinship ties between indigenous communities having fraternal relations)

c. panas gandong (to strenghthen kinship relationship of relatives)

d. Yelim (tradition of helping each other when happy or hard)

e. Moritari (art or rule of life in the race of doing good)

f. Kalwedo (sharing greetings, joyful spirit and peace in a strong cultural bond), etc.

Therefore, to realize true peace for Ambon's communities, besidean encounter space, a public space must also be able to represent the living atoran and tradition. Here is an example or model of public spaces that the Ambon's communities need, especially in the border area between 2 or more segregated settlers:

\footnotetext{
1 Watloly, dkk. 2016, Perdamaian Berbasis Adat Orang Bersaudara, PT Kanisius, Yogyakarta, hal. 27-36.

2 lbid hal. 71,72

3 lbid hal. 74

${ }^{4}$ lbid. Hal. 78

5 lbid. Hal. 79
} 


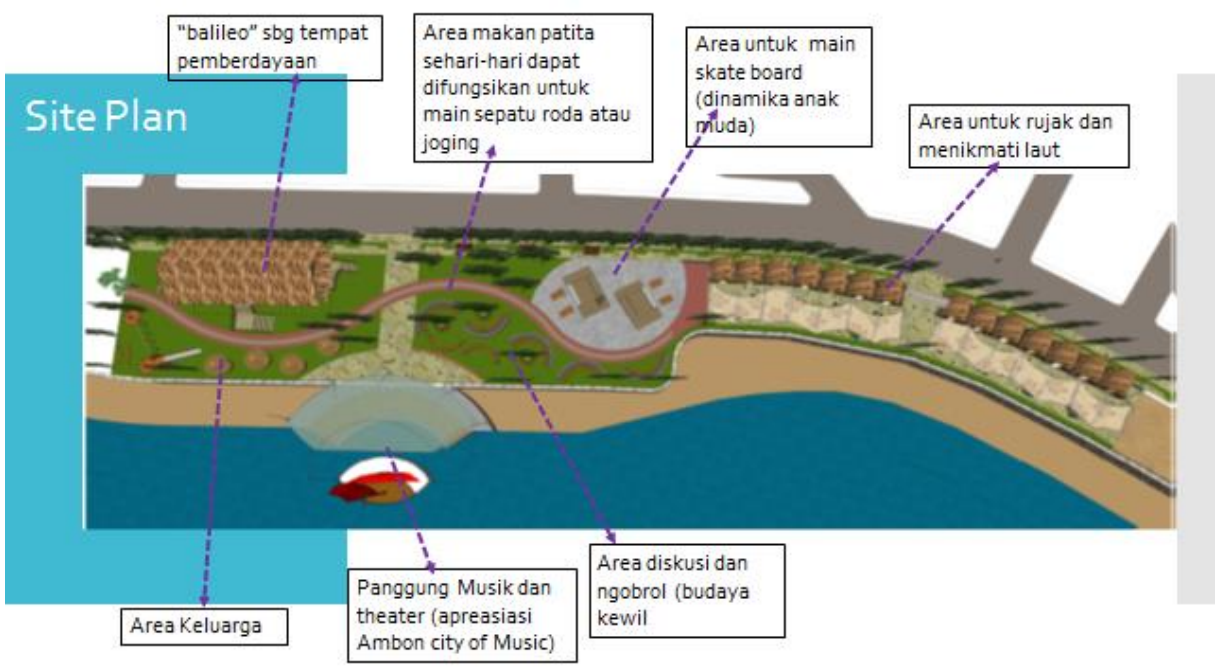

\section{E. Conclusion}

The inculturation process of a public space means the process of cultural initiation of "Orang Basudara" of Ambon's communities that elevates local cultural values as part of the work of peace proclamation. This enforces a life-loving process as brothers and sisters and to avoid violence and this can be one of the ways to resolve any conflict. Through the inculturation process in the public space, peace proclamation will be well received by the local communities according to the languages of individuals and cultures that have grown and rooted in Ambonese plural communities. Therefore, the public space inculturation that performs as a reciprocal relationship among individuals and communities that interact in that space having Orang Basudara culture is expected to merge in the rules, limitations and meanings of the social order of the Ambon's communities to lead a lasting peaceful life. 